\section{The role of physicians in the violence epidemic}

According to the World Health Organization, preventing violence is a multifaceted mandate of public health, which requires strategies that are adapted to local and national social contexts. ${ }^{1}$ In an editorial, Dr. Matthew Stanbrook argues that physicians should play a role in advocating for gun control from a public health perspective. ${ }^{2}$ Brian Owens' arti$\mathrm{cle}^{3}$ on the role of physicians in addressing gun violence emphasizes not only the much-needed role of physicians in developing policies on gun safety, but also the existence of social and political obstacles to this form of advocacy in North America.

Now, if the objective, as Owens rightly proposes, is to stop shooters before they shoot, then gun safety and gun control, although absolutely necessary, must be complemented with policies and programming that reflect and address other social determinants of violence and the precursors of violent acting-out identified across the scientific and threat-related literature. ${ }^{4}$

Trajectory analyses of lone actors have identified relatively nonmodifiable factors (like childhood abuse), and modifiable ones (like social isolation, absence of a sense of purpose) and, to a certain extent, psychopathology. ${ }^{5}$ Specialized clinical work may modify depression levels, treat psychosis and trauma, and address cognitive rigidity. ${ }^{6}$ Mentoring programs in Denmark have been successful in improving social integration. ${ }^{7}$ Some of these factors can be targeted by prevention and intervention programs.
First, the well-known imitation and contagion phenomena after mass killings (school shootings, for example), are associated with media coverage of these events. ${ }^{8}$ The Institut national de santé publique du Québec just released recommendations to equip the media in order to minimize these effects. ${ }^{9}$ However, the influence of the Internet and social media, fuelling hate discourses and the glorification of active shooters, must still be addressed. Second, researchers in education and sociology have suggested ${ }^{10}$ a connection between histories of interpersonal violence and pervasive uncertainties for the future and attraction to extreme forms of violent action among youth, with violence providing a sense of purpose and intense feelings of excitement for isolated and socially disengaged individuals. Finally, as suggested by the overrepresentation of persons with mental disorders among lone actors, some psychologically distressed individuals are more vulnerable to these social trends and may be more likely to move from legitimizing violence to perpetrating violent acts. ${ }^{5}$

Thus, we believe that health professionals should become involved in broader initiatives that may prevent violence. These initiatives include promoting more effective gun control and firearm safety, supporting recommendations for media reporting of gun violence by lone actors (as is the case for suicide), developing partnerships with the education system to address youth psychosocial well-being and, as always, addressing individual-level psychological distress with an awareness that it may, in some cases, lead to desperate and violent gestures.

\section{Cécile Rousseau MD MSc}

Professor, McGill University, Montréal, Que.

\section{Ghayda Hassan PhD}

Professor, L'Université du Québec à

Montréal, Montréal, Que.

\section{Rochelle Frounfelker ScD MPH}

Postdoctoral student, McGill University, Montréal, Que.

Cite as: CMAJ 2019 June 10;191:E644. doi: $10.1503 / \mathrm{cmaj} .72017$

\section{References}

1. Eisenman DP, Flavahan L. Canaries in the coal mine: interpersonal violence, gang violence, and violent extremism through a public health prevention lens. Int Rev Psychiatry 2017;29:341-9.

2. Stanbrook M. Gun control: a health issue for which physicians rightfully advocate. CMAJ 2019;191:E434-5.

3. Owens B. Gun violence is an epidemic and "we solve epidemics with medicine, not politics." CMAJ 2019;191:E59-60.

4. Silver J, Simons A, Craun S. A study of the pre-attack behaviors of active shooters in the United States between 2000 and 2013. Washington (D.C.): Federal Bureau of Investigation, US Department of Justice; 2018.

5. Gill P, Silver J, Horgan J, et al. Shooting alone: the pre-attack experiences and behaviors of US solo mass murderers. J Forensic Sci 2017; 62:710-4.

6. Ben-Cheikh I, Rousseau C, Hassan G, et al. Intervention en contexte de radicalisation menant à la violence: une approche clinique multidisciplinaire. Revue Santé mentale au Québec 2018;43: 85-99.

7. Bertelsen P. Danish preventive measures and deradicalization strategies: the Aarhus model. Panorama: Insights into Asian and European Affairs 2015;1: 241-53.

8. Lankford A, Madfis E. Media coverage of mass killers: content, consequences, and solutions. Am Behav Sci 2018;62:151-62.

9. Institut national de santé publique du Québec. Mass killings and media treatment: a tool for information media professionals [article in French]. Quebec: Government of Quebec; 2019:20.

10. Venkatesh V, Podoshen JS, Wallin J, et al. Promoting extreme violence: visual and narrative analysis of select ultraviolent terror propaganda videos produced by the Islamic State of Iraq and Syria (ISIS) in 2015 and 2016. Terror Polit Violence 2018;1-23. doi: 10.1080/09546553.2018.1516209.

Competing interests: None declared. 